\title{
ARTERIAL PRESSURE AND DELTOID MUSCLE GAS TENSIONS DURING CARDIOPULMONARY BYPASS IN MAN
}

\author{
THEOdORE H. STANLEY
}

SKeletal MUSCle OXYGEN $\left(\mathrm{Pm}_{\mathrm{O}_{2}}\right)$ and carbon dioxide tensions $\left(\mathrm{Pm}_{\mathrm{CO}_{2}}\right)$ are related to muscle perfusion. ${ }^{1-3} \mathrm{~A}$ number of reports have demonstrated that with decreasing peripheral tissue perfusion, depression of $\mathrm{Pm}_{\mathrm{O}_{2}}$ and elevation of $\mathrm{Pm}_{\mathrm{CO}_{2}}$ occur significantly sooner than comparable changes in mixed venous or arterial blood gases and $\mathrm{pH},{ }^{1-3}$ While good peripheral tissue perfusion is an ideal to be striven for in cardiopulmonary bypass during open-heart operations, there is still considerable controversy regarding what are optimal pressures and flows during bypass and what perfusion or metabolic variables best indicate adequacy of peripheral tissue perfusion. In this study we measured deltoid muscle $\mathrm{Pm}_{\mathrm{O}_{2}}$ and $\mathrm{Pm}_{\mathrm{CO}_{2}}$ in man before and during cardiopulmonary bypass and investigated the influence of changes in mean arterial blood pressure (BP) during bypass on $\mathrm{Pm}_{\mathrm{O}_{2}}$ and $\mathrm{Pm}_{\mathrm{CO}_{2}}$.

\section{METHODS}

The study was approved by the Wilford Hall USAF Medical Center Human Study Committee. Informed written consent was obtained from every patient at the pre-operative visit. A total of 32 patients scheduled for aortic valve replacement or coronary artery revascularization operations made up the experimental subjects.

Premedication included pentobarbitone (1 $\mathrm{mg} / \mathrm{kg}$ ) or diazepam (1 $\mathrm{mg} / 10 \mathrm{~kg}$ ), morphine (1 $\mathrm{mg} / 10 \mathrm{~kg})$ and atropine $(0.05 \mathrm{mg} / 10 \mathrm{~kg})$ given intramuscularly 90 minutes before the scheduled time of operation. Pre-operative preparation and intra-operative blood and fluid management schedules have been previously described. ${ }^{4,5} \mathrm{~Pa}$ tients were anaesthetized either with halothane (1 to 2 per cent) or with morphine ( 1 to $3 \mathrm{mg} / \mathrm{kg}$ ) plus oxygen and paralyzed with succinylcholine (1.5 $\mathrm{mg} / \mathrm{kg}$ ). The trachea was then intubated and respiration was controlled to maintain $\mathrm{Paco}_{2}$ be-

Theodore H. Stanley, M.D. Associate Professor of Anesthesiology/Surgery. Department of Anesthesiology. The University of Utah College of Medicine, 50 North Medical Drive, Salt Lake City, Utah 84132, and Wilford Hall USAF Medical Center, Lackland AFB, San Antonio, Texas, 78236.

Canad. Anaesth. Soc. J., vol. 25, no. 4, July 1978 tween 4.7 and $5.3 \mathrm{kPa}$ ( 35 and 40 torr) as has been previously described. ${ }^{4,5}$ Muscle paralysis was maintained with curare 0.5 to $0.75 \mathrm{mg} / \mathrm{kg}$. After induction of anaesthesia a Scientific Research Instruments Corp. Teflon tissue catheter, previously calibrated in lactated Ringer's solution, was implanted into either the right or left del toid muscle through a 12-gauge catheter inserted percutaneously into the muscle. The tefion catheter was attached to a Medspect MN-8 mass spectrometer which continuously sampled and measured muscle oxygen, carbon dioxide and nitrogen.

The cardiopulmonaly bypass system consisted of a Bently bubble oxygenator and Sarns roller pump and was primed with lactated Ringer's solution. $\mathrm{Pa}_{\mathrm{O}_{2}}$ was maintained between $20-26.6 \mathrm{kPa}$ (150-200 torr) during bypass, $\mathrm{PaCO}_{2}$ between 4.5-5.3 kPa (35-40 torr), temperature at $30^{\circ} \mathrm{C}$ and flow initially at rates necessary to keep the bypass common venous return oxygen tension $\left(\mathrm{P} \bar{v}_{0_{2}}\right)$ at 4.9 to $5.6 \mathrm{kPa}$ (37-42 torr). $\mathrm{Pa}_{\mathrm{O}_{2}}, \mathrm{~Pa}_{\mathrm{CO}_{2}}$, arterial $\mathrm{pH}, \mathrm{Pm}_{\mathrm{O}_{2}}$ and $\mathrm{Pm}_{\mathrm{CO}_{2}}$ were recorded immediately before and 15 to 20 minutes after initiation of bypass, when flow and pressure had stabilized. Mixed venous $\mathrm{PO}_{2}, \mathrm{PCO}_{2}$ and $\mathrm{pH}$ could not be measured before bypass but were measured after its initiation. Following this, in 16 patients mean arterial blood pressure $(\overline{\mathrm{BP}})$ was increased by increments of $1.3 \mathrm{kPa}$ (10 torr) from initial values of $5.3-6.7 \mathrm{kPa}(40-50$ torr) to 13.3-14.6 kPa (100-110 torr) by increasing flow rate. On occasion it was necessary to add additional lactated Ringer's solution to the bypass to sustain high flow rates. In an additional 16 patients $\overline{\mathrm{BP}}$ was raised in a similar fashion by infusing a dilute ( 0.1 per cent) solution of ephedrine. Arterial and mixed venous blood gases and $\mathrm{pH}$, $\mathrm{Pm}_{\mathrm{O}_{2}}$ and $\mathrm{Pm}_{\mathrm{CO}_{2}}$ were measured 15 minutes after each change of $\overline{\mathrm{BP}}$.*

*In four patients in each of the two groups $\overline{\mathrm{BP}}$ was immediately increased to $13.3-14.6 \mathrm{kPa}(100-110$ torr) and then reduced by $1.33 \mathrm{kPa}$ ( 10 torr) increments back to initial values. In both groups $\mathrm{Pm}_{\mathrm{O}_{2}}$ and $\mathrm{Pm}_{\mathrm{CO}_{2}}$ were similar within a given range of $\overline{\mathrm{BP}}$ to values obtained during increases of $\overline{\mathrm{BP}}$. Therefore, data obtained during increasing and decreasing mean arterial blood pressure were combined. 


\section{RESULTS}

$\mathrm{Pa}_{\mathrm{O}_{2}}, \mathrm{~Pa}_{\mathrm{CO}_{2}}, \mathrm{P} \overline{\mathrm{CO}}_{2}$, arterial and mixed venous $\mathrm{pH}$ were not significantly changed by increases of bypass $\overline{\mathbf{B P}}$ achieved by increases in flow or infusion of ephedrine. $P \bar{v}_{\mathrm{O}_{2}}$ averaged $5.2 \pm 0.3 \mathrm{kPa}$ ( $39 \pm 2$ torr) 15 minutes after initiation of bypass and increased in direct proportion to pressure increases resulting from increases in bypass flow (Table I). Ephedrine also increased $\mathrm{P} \bar{v}_{\mathrm{O}_{2}}$ but this change was only significant at bypass pressures of 10.6 to $12 \mathrm{kPa}$ ( $80-90$ torr). In all 32 patients pre-bypass $\mathrm{Pm}_{\mathrm{O}_{2}}$ averaged $4.4 \pm 0.6 \mathrm{kPa}(33 \pm 4$ torr) and $\mathrm{Pm}_{\mathrm{CO}_{2}}$ averaged $5.5 \pm 0.6 \mathrm{kPa}(41 \pm 4$ torr) (Table l). Initial flow rates 15 to 20 minutes after initiation of bypass averaged $6 \pm 0.8 \mathrm{kPa}(45$ \pm 6 (orr) and ranged between 5.2 and $6.9 \mathrm{kPa}$ (39-52 torr). These flows and mean blood pressures resulted in mean $\mathrm{Pm}_{\mathrm{O}_{2}}$ values of $0.4 \pm 0.2$ $\mathrm{kPa}\left(3 \pm 2\right.$ torr) and mean $\mathrm{Pm}_{\mathrm{Co}_{2}}$ of $9.6 \pm 0.9 \mathrm{kPa}$ ( $72 \pm 7$ torr)

Increases in $\overline{\mathrm{BP}}$ achieved by greater bypass flow rates did not significantly change $\mathrm{Pm}_{\mathrm{O}_{2}}$ or $\mathrm{Pm}_{\mathrm{CO}_{2}}$ until $\overline{\mathrm{BP}}$ s of 9.3 to $10.6 \mathrm{kPa}$ (70 to 80 torr) were reached. With $\overline{\mathrm{BP}}$ between 12 and $14.6 \mathrm{kPa}$ (90 and $\mathrm{l} l 0$ torr) $\mathrm{Pm}_{\mathrm{O}_{2}}$ and $\mathrm{Pm}_{\mathrm{CO}_{2}}$ were similar to values measured immediately before bypass. In contrast, increases in $\overline{\mathrm{BP}}$ achieved by ephedrine infusion did not significantly change $\mathrm{Pm}_{\mathrm{O}_{2}}$ or $\mathrm{Pm}_{\mathrm{CO}_{2}}$ until $\overline{\mathrm{BP}}$ was more than $12 \mathrm{kPa}(90$ torr) and even with $\overline{\mathrm{BP}}$ between 13.3 and $14.6 \mathrm{kPa}$ (100 and 110 torr) $\mathrm{Pm}_{\mathrm{O}_{2}}$ was significantly lower and $\mathrm{Pm}_{\mathrm{CO}_{2}}$ higher than pre-bypass control values.

\section{Discussion}

Despite well established techniques for instituting and maintaining cardiopulmonary bypass there is still considerable controversy about the best methods of monitoring the adequacy of perfusion during bypass. It has been suggested, for example, that perfusion will usually be ideal if pump flow rates are maintained at 2.3 to 2.5 $1 / \mathrm{kg} / \mathrm{m}^{2}$ of body surface area or above $40-50$ $\mathrm{ml} / \mathrm{kg} / \mathrm{min}$ in adults during moderate hypothermia $\left(30-32^{\circ} \mathrm{C}\right) .^{6-8}$ Others have demonstrated that arterial blood pressures must be maintained above a mean of $8 \mathrm{kPa}$ ( 60 torr), irrespective of flow rate. ${ }^{9}$ Still others (Martin, W.E., personal communication) have suggested that, rather than flow or pressure, arterial-mixed venous oxygen content difference or mixed venous oxygen saturation should be carefully monitored and maintained within certain limits to ensure adequate bypass perfusions. A few years ago we showed that regulating bypass flow rates to ensure a nor- mal $\mathrm{Pv}_{\mathrm{O}_{2}}$ was superior to perfusing at a fixed calculated flow rate. ${ }^{10}$ Since that report, this technique has become a popular method of conducting bypass."

The results of this study demonstrate that regulation of flow rates during cardiopulmonary bypass to maintain normal $\mathrm{PV}_{\mathrm{O}_{2}}(4.9-5.6 \mathrm{kPa}$; 37-42 torr) produces normal arterial and mixed venous $\mathrm{pH}$ but does not ensure a normal $\mathrm{Pm}_{\mathrm{O}_{2}}$ and thus normal perfusion to muscle. In addition, our data demonstrate that muscle oxygen tensions are reduced and carbon dioxide tensions elevated during bypass at low blood pressure and do not return to pre-bypass levels until $\overline{\mathrm{BP}}$ is more than $12 \mathrm{kPa}$ (90 torr). They also indicate that even high $\overline{\mathrm{BP}}$ s are not associated with $\mathrm{Pm}_{\mathrm{O}_{2}}$ and $\mathrm{Pm}_{\mathrm{Co} z}$ values similar to those of the pre-bypass period when bypass $\overline{\mathrm{BP}}$ is elevated with a pressor. The data suggest that both high pressure and high flow rate are necessary during bypass to ensure normal muscle perfusion and that utilization of pressors during bypass can maintain high levels of $\overline{\mathbf{B}} \overline{\mathbf{P}}$ but at the expense of muscle blood flow.

In a recent survey Garman* showed that in 19 anaesthesia groups at major cardiac surgery centres, adult bypass flow rates and $\overline{\mathrm{BP}}$ considered ideal ranged between 30 to $80 \mathrm{ml} / \mathrm{kg} / \mathrm{min}$ and 6.4 to $14.4 \mathrm{kPa}$ (48 to 109 torr) respectively, at moderate hypothermia $\left(30-32^{\circ} \mathrm{C}\right)$. Perfusion techniques at most of these centres were similar to those reported in this study. These data, when combined with our findings in the present investigation, suggest that muscle perfusion during bypass in many of these centres is inadequate. Whether it is necessary or even desirable to perfuse muscle during non-pulsatile extra-corporeal circulation in man is unknown at this time. However, in a recent series of experiments we (Stanley, T.H. and Webster, L.R., unpublished data) have observed that calves undergoing cardiopulmonary bypass with flow rates adjusted to maintain normal (pre-bypass) $\mathrm{Pm}_{\mathrm{O}_{2}}$ and $\mathrm{Pm}_{\mathrm{CO}_{2}}$ have less decrease in body temperature and less anaerobic metabolism after bypass, are able to stand and sustain normal respiratory rates and tidal volumes after operation sooner, fulfill the criteria for tracheal extubation earlier and have less post-operative atelactasis and pneumonia than calves having bypass flow rates fixed at $60-80 \mathrm{ml} / \mathrm{kg} / \mathrm{min}$ (or approximately $2.5-3.0$ $\left.1 / \mathrm{kg} / \mathrm{m}^{2}\right) \dagger$ or adjusted to maintain $\mathrm{P} \bar{v}_{0_{2}}$ within normal limits (5-5.6 kPa; 37-42 torr).

\footnotetext{
* Garman, J.K., personal communication.

$\dagger$ The se flow rates are considered to be adequate for bypass at $30^{\circ} \mathrm{C}$ in a three-month-old calf.
} 


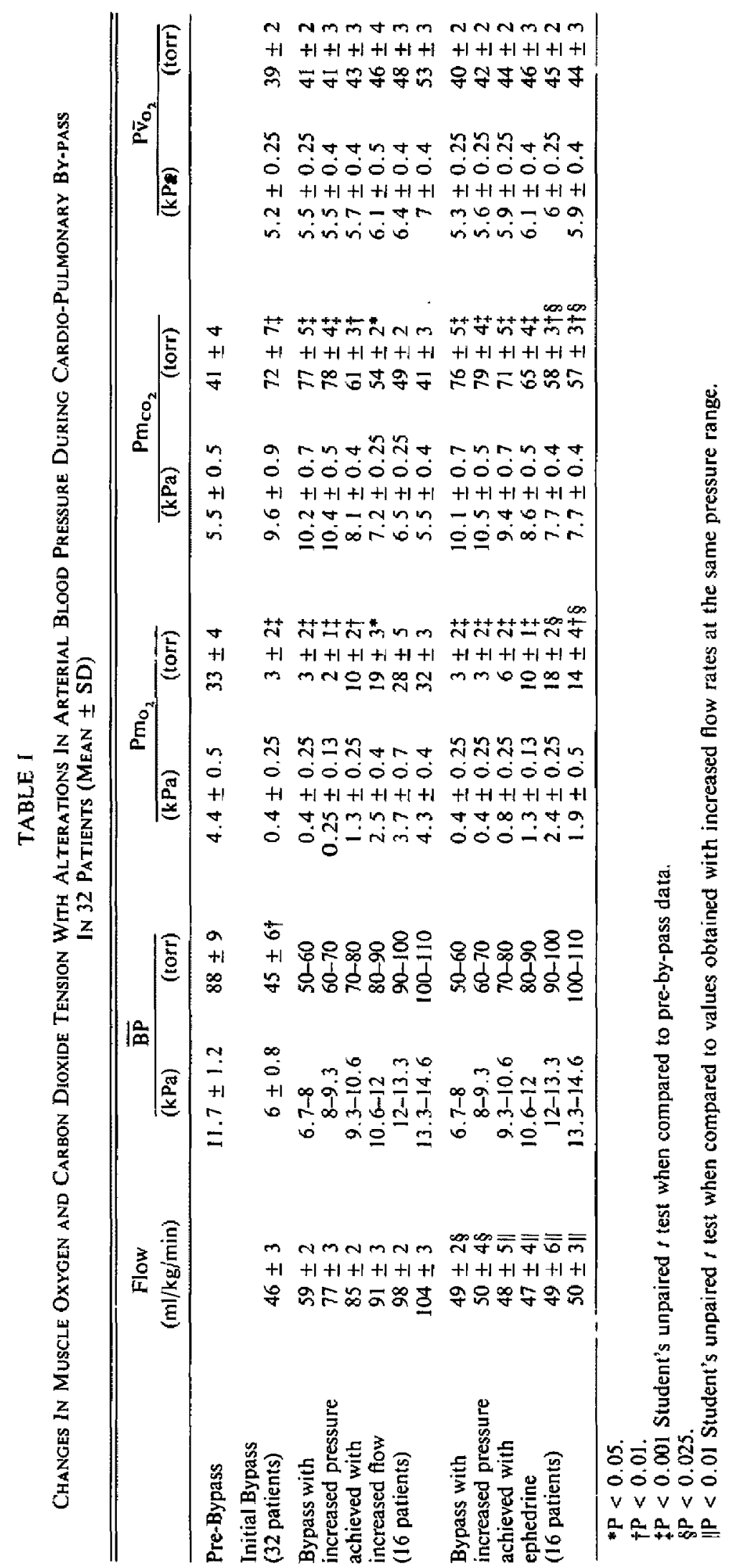


While these findings must be considered preliminary, they do suggest that perfusion during bypass designed to maintain $\mathrm{Pm}_{\mathrm{O}_{2}}$ and $\mathrm{Pm}_{\mathrm{CO}_{2}}$ at pre-bypass values offers advantages, at least in the calf, when compared to usual perfusion techniques. Unfortunately, because of the protocol employed, technical limitations of the Teflon catheters and other clinical limitations, it was not possible in man to examine carefully any of the post-bypass and post-operative variables we studied in the calf. Therefore there is, as yet, no evidence available in man to substantiate that perfusion during bypass to maintain $\mathrm{Pm}_{\mathrm{O}_{2}}$ and $\mathrm{Pm}_{\mathrm{CO}_{2}}$ at pre-bypass values is any better than usual perfusion techniques. Recent studies ${ }^{2}$ and continuing developments in devices to measure tissue gas tensions should enable a carefully controlled study to be done evaluating the importance of muscle perfusion during bypass in man.

\section{SUMmarY}

The results of this study demonstrate that standard techniques of conducting cardiopulmonary bypass produce low muscle oxygen and high muscle carbon dioxide tensions and, thus, little perfusion of skeletal muscle. Our findings also show that $\mathrm{Pm}_{\mathrm{O}_{2}}$ and $\mathrm{Pm}_{\mathrm{CO}_{2}}$ do not return to pre-bypass levels until the mean arterial blood pressure exceeds $12 \mathrm{kPa}$ (90 torr) during bypass and that utilization of vasopressor drugs during bypass maintains the pressure; but at the expense of muscle blood flow. The data indicate that both high mean blood pressure and high flow are necessary during bypass to ensure skeletal muscle perfusion and suggest, when combined with preliminary animal findings, that this type of bypass perfusion may prove to be superior to standard techniques in hastening recovery after cardio-pulmonary bypass.

\section{RÉSUMÉ}

Les effets de la variation de la pression de perfusion pendant la circulation extra corporelle (C.E.C.) sur la tension en oxygène $\left(\mathrm{Pm}_{\mathrm{O}_{2}}\right)$ et en gaz carbonique $\left(\mathrm{Pm}_{\mathrm{CO}_{2}}\right)$ du muscle deltoïde ont été étudiés chez 32 malades. La $\mathrm{Pm}_{\mathrm{O}_{2}}$ et la $\mathrm{Pm}_{\mathrm{CO}_{2}}$ furent mesurées immédjatement avant et après stabilisation du débit et de la pression de perfusion, soit 15 à 20 minutes après la mise en marche de la C.E.C. Ensuite chez la moitié des patients, on a fait monter la pression de perfusion sous CEC par échelons de $1.33 \mathrm{kPa}$ (10 torr) à partir de 5.3 à $6.7 \mathrm{kPa}$ (40à 50 torr) jusqu'à 13 à $15 \mathrm{kPa}(100$ à 110 torr) en augmentant le débit de la pompe. Chez l'autre moitié, on a obtenu les mèmes résultats en perfusant avec une solution diluée d'éphédrine.

La pression de perfusion initiale sous C.E.C. était en moyenne de $6 \pm 0.8 \mathrm{kPa}(45 \pm 6$ torr) et le débit de la pompe de $46 \pm 3 \mathrm{ml} / \mathrm{kg} / \mathrm{min}$ alors que la $\mathrm{Pm}_{\mathrm{O}_{2}}$ était de $0.4 \pm 0.3 \mathrm{kPa}(3 \pm 2$ torr $)$ pour une $\mathrm{Pm}_{\mathrm{CO}_{2}}$ de $9.6 \pm 0.9 \mathrm{kPa}(72 \pm 7$ torr). L'élévation de la pression de perfusion obtenue par augmentation du débit de pompe n'a pas faít varier la $\mathrm{Pm}_{\mathrm{O}_{2}}$ et la $\mathrm{Pm}_{\mathrm{CO}_{2}}$ avant qu'elle n'atteigne 9.3 à $10.6 \mathrm{kPa}$ (70 à 80 torr). Ce n'est qu'à partir de ce niveau que la $\mathrm{Pm}_{\mathrm{O}_{2}}$ s'est mise à monter et que la $\mathrm{Pm}_{\mathrm{CO}_{2}}$ à baisser. Avec une pression de perfusion de 12 à $14.6 \mathrm{kPa}$ (90à 110 torr) la $\mathrm{Pm}_{\mathrm{O}_{2}}$ et la $\mathrm{Pm}_{\mathrm{CO}}$ étaient identiques aux valeurs mesurées immédiatement avant la C.E.C. Par contre, l'aug. mentation de la pression de perfusion provoquée par l'éphédrine n'a pas fait varier la $\mathrm{Pm}_{\mathrm{O}_{2}}$ et la $\mathrm{Pm}_{\mathrm{CO}_{2}}$ avant que la pression n'atteigne $12 \mathrm{kPa}$ ( 90 torr) et même avec des pressions de l'ordre de 13.3 à $14.6 \mathrm{kPa}$ ( 100 à 110 torr), la $\mathrm{Pm}_{\mathrm{O}_{2}}$ demeura plus basse et la $\mathrm{Pm}_{\mathrm{CO}_{2}}$ plus élevée d'une façon significative que les valeurs de contrôle mesurées avant la C.E.C. Ces données démontrent que les techniques habituelles de C.E.C. font baisser la tension en oxygène et monter la tension en gaz carbonique mesurées au niveau des muscles et prouvent que le muscle squelettique est mal perfusé; que la $\mathrm{Pm}_{\mathrm{O}_{2}}$ et le $\mathrm{Pm}_{\mathrm{CO}_{2}}$ ne reviennent aux niveaux qui précédaient la C.E.C. que lorsqu'une pression de $12 \mathrm{kPa}$ (90 torr) est atteinte durant la C.E.C. et que l'utilisation de vasopresseurs durant la perfusion maintient la pression mais au dépend du flux sanguin musculaire. Nos résultats démontrent aussi qu'une pression de perfusion élevée ainsi que de haut débits sont nécessaires pendant la C.E.C. pour produire une perfusion musculaire suffisante et nous permettent de penser que ce type de perfusion pourrait amener une récuperation plus rapide après la C.E.C.

\section{REFERENCES}

1. Furuse, A., Brawley, R.K., Struve, E., \& GoTT, V.L. Skeletal muscle gas tension: indicator of cardiac output and peripheral tissue perfusion. Surgery $74: 214$ (1973).

2. Filler, R.M. \& Das, J.B. Muscle pH, $\mathrm{PO}_{2}, \mathrm{PCO}_{2}$ monitoring: a review of laboratory and clinical evaluations. Adv. Exp. Med. Biol. 50 : 175 (1974).

3. Wakabayashi, A., Yoshimasa, N., WoOlley, T., Mullin, P.J., Watanabe, H., Takashi, I., \& ConNolly, J.E. Continuous percutaneous monitoring of muscle $\mathrm{pH}$ and oxygen pressure. Arch. Surg. 110:802 (1975). 
4. Stanley, T.H., Gray, N.H., Stanford, W., \& ARMSTrong, $R$. The effects of high-dose morphine on fluid and blood requirements of open-heart operations. Ane sthesiology 38: 536 (1973).

5. Stanley, T.H., Gray, N.H., Isern-Amaral, J.A., \& PATton, C. Comparison of blood requirements during morphine and halothane anesthesia for open-heart surgery. Anesthesiology 4I: 34 (1974).

6. MCGoon, D.C., Moffitt, E.A., Theye, R.A., \& KIrkIN, J.W. Physiologic studies during high flow, normothermic, whole body perfusion. J. Thoracic Cardiovase. Surg. 39: 275 (1969).

7. Zuhdi, N., Carey, J., Cutter, J., Rader, L., \& Greer, A. Intentional hemodilution. Arch. Surg. 87: 554 (1963).
8. ANDERSon, M.N. \& RAvdin, I.S. What is "optimum flow rate?" Surgery 43: 1021 (1956).

9. Tufo, H.M., Ostfeld, A.M., \& Shekelle, R. Central nervous system dysfunction following open-heart surgery, J.A.M.A. 212: 1333 (1970).

10. Stanley, T.H. \& Isern-Amaral, J.H. Periodic analysis of mixed venous oxygen tension to monitor the adequacy of perfusion during and after cardiopulmonary bypass. Canad. Anaesth. Soc. J. 21: 454 (1974).

11. Berger, R.L. \& Norman, J.C. Cardiac surgery. Ed. J. Norman. New York, Appleton-CenturyCrofts, Chap. 6(1972). 